University of Rhode Island

DigitalCommons@URI

Open Access Master's Theses

1990

\title{
A GIS Macro to Estimate the Impact of Changing Buffer Widths Around Wetlands on Property Taxes
}

Mary F. Hutchinson

University of Rhode Island

Follow this and additional works at: https://digitalcommons.uri.edu/theses

\section{Recommended Citation}

Hutchinson, Mary F., "A GIS Macro to Estimate the Impact of Changing Buffer Widths Around Wetlands on Property Taxes" (1990). Open Access Master's Theses. Paper 662.

https://digitalcommons.uri.edu/theses/662

This Thesis is brought to you for free and open access by DigitalCommons@URI. It has been accepted for inclusion in Open Access Master's Theses by an authorized administrator of DigitalCommons@URI. For more information, please contact digitalcommons-group@uri.edu. 


\begin{abstract}
A GIS MACRO
TO ESTTMATE THE IMPACT

OF

CHANGING BUFFER WIDIHS AROUND WEILANDS

ON PROPERTY TAXES
\end{abstract}

BY

MARY F. HUICHINSON

\begin{abstract}
A RESEARCH PROJECT SUDMMITTED IN
PARIIAL FULFIIIMENT OF THE REQUIREMENIS

FOR THE DEGREE AND MASTER OF COMUNITY PLANNING
\end{abstract}

UNIVERSITY OF RHODE ISLAND

1990 


\section{MASTER OF COMMUNITY PLANNING}

\section{RESEARCH PROJECT}

OF

MARY F. HUTCHINSON

Approved:

Major Professor

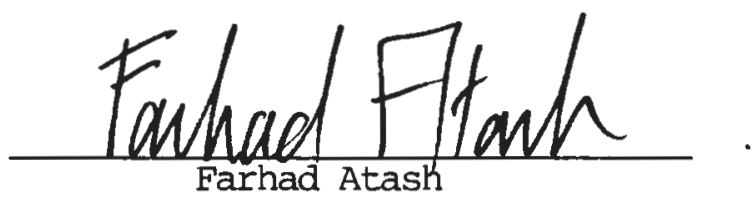

Acknowledged:

Director

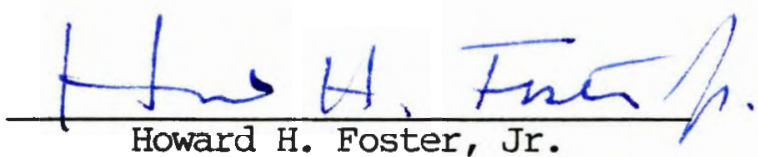




\section{A C K NOW LE D G E M N T S}

Many people have contributed to the conduct of this research. I am indebted to the Town of New Shoreham and Block Island Land Trust for their valiant efforts in establishing a municipal geographic information system. The ability to use authentic spatial and tabular data was invaluable for this research, particularly for the pilot study area analysis.

I extend my sincerest appreciation to Dr. Farhad Atash for his interest, advice and critical appraisal in this research, and to Dr. Peter August for the conception of this research and input throughout.

Planning Board Secretary Dorothy McCluskey and Tax Assessor Martha Smith for their time and interest.

The staff at the Environmental Data Center for their support and in particular Christopher Smith for his assistance on some intriacte technical questions.

The Town of New Shoreham's GIS Coordinator and fellow graduate student, Amy Bell, for her support and assistance, who was always willing and able to teach me a new command or show me a simpler way!

A final acknowledgement to Jim for having patience and giving love and support throughout this study. Thank you. 
PAGE

Acknowledgements $\ldots \ldots \ldots \ldots \ldots \ldots \ldots \ldots \ldots \ldots$ ii

List of Tables $\ldots \ldots \ldots \ldots \ldots \ldots \ldots \ldots \ldots \ldots \ldots$ iv

List of Figures $\ldots \ldots \ldots \ldots \ldots \ldots \ldots \ldots \ldots \ldots \ldots \ldots$ v

CHAPTER

I Introduction $\ldots \ldots \ldots \ldots \ldots \ldots \ldots \ldots \ldots \ldots \ldots \ldots$ I

II Background To Macro Development ............ 5

III Methodology of Macro Operation.............. 16

IV Pilot Study Area and Data ............... 23

V Pilot Study Area Analysis ................ 28

VI Conclusions and Policy Implications........... 39 


\section{I S T OF T A B L E S}

TABLE

PAGE

1 Comparison of Wetland Areas From

Different Sources ..................... 29

2 Introduction of RIGIS Wetlands and Variation of

"Waste Acreage" Definition on 1987 Database ...... 31

3 Estimated Fiscal Impacts from Spatial Error ..... 32

4 Estimated Fiscal Impacts from Increasing Buffer

Widths Around Wetlands ..................... 33

$5 \quad$ Frequency of Lots with Property Tax Loss ....... 34

6 Comparison of Total Lot Area From

Different sources .................... 37 


\section{I S T O F F I G U R E S}

FIGURE

FOLIOWING PAGE

1 Components of a Flow Chart .............. 22

2 Flow Chart of FIA Macro $\ldots \ldots \ldots \ldots \ldots \ldots \ldots \ldots . . . . .22$

3 Location of Pilot Study Area .............. 23

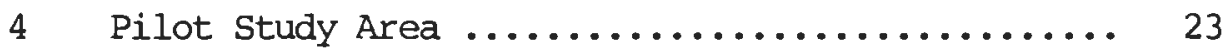

5 Fresh Water Wetlands In Pilot Study Area ....... 25

6 Value Per Acre of "Excess Acreage" ........... 30

7 Average Tax Loss When Buffers Excluded From "Waste Acreage" ....................... 32

8 Average Tax Loss When Buffers Included In "Waste Acreage" ...................... 32

9 Average Tax Loss When Buffers Increased To 100 Feet ............................. 34

10 Average Tax Loss When Buffers Increased To

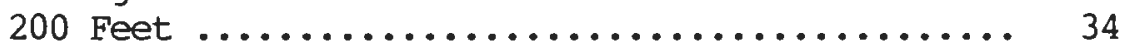

11 Average Tax Loss When Buffers Increased To 300 Feet ............................. 34 


\section{H A P T E R O N E}

\section{TNIRODUCTION}

As development pressure increases along the coastal regions of the United States, it becomes increasingly important that greater attention be paid to the fringe areas surrounding coastal and fresh water wetlands. (Brady \& Buschman, 1989). Development within these fringe areas can cause changes that damage or even destroy wetland habitats. Wetlands perform many valuable functions that enhance natural and human systems, such as the provision of habitat to a diverse range of plants and animals, flood storage, ground water recharge, and the removal of pollutants from urban runoff such as waterborne chemicals and nutrients. Vegetated buffers around wetlands serve as an extremely valuable nonpoint source pollutant control mechanism, control soil erosion, and protect vegetation, fisheries and wildlife habitat. These buffers also enhance the aesthetic quality of the natural and built environments.

Presently a fifty foot buffer is required around the upland area of fresh water wetlands regulated by the Rhode Island Department of Environmental Management (R.I.G.L. 2-1-15). There is concern that this width is inadequate to protect some of those statutory interests. Several environmental groups and agencies are suggesting that these buffers in particular should range from 100 to 300 feet in width, and more in the case of threatened or endangered species (Groffman et. al, 1990; Brady \& Buschman, 1989).

Recently the City of Gloucester in Massachusetts increased the width of vegetated buffer zones around the Essex Bay - Parker River Area of 
Critical Environmental Concern in order to protect this valuable resource. The Massachusetts Audobon Society: North Shore (MAS:NS) had advocated that the vegetated buffer zones be increased from 100 feet to 300 feet, among other management initiatives. In-line with the political complexities of decision-making both the City and MAS:NS compromised and settled on a width of 200 feet.

If the City had been able to quickly analyze the fiscal impacts of various buffer widths, such as 150, 200, 250 or 300 feet, and with little cost, this additional information might (or might not) have resulted in a different buffer width. A sensitivity analyses might have revealed that there was a point where the negative fiscal impact could be minimized and the buffer width maximized, a win-win situation for both the environmental group and the taxpayer/community. To have performed this fiscal impact analysis manually would have been costly, time-consuming and difficult to manage all the data. It is likely that the fiscal analysis, if done at all, was left to "back-of-the-envelope" type calculations (Brady, 1990). A geographic information system (GIS) would have enabled an analysis to be quickly performed.

Decision-makers need to know more about the economics of environmental policies and regulations. Not only do they need to know this in a timely manner but also with a degree of confidence. With local governments under tight budgetary constraint and highly dependent on the real property tax for revenue, the need to have information on the fiscal impacts of changes in regulations is essential. Politicians and elected officials generally ask two questions when considering policy - "what is it" and "how much will it cost?". This research provides decision-makers 
with technical information in answering the second question.

The fundamental objective of this research is to demonstrate the usefulness of GIS for fiscal impact analysis in two ways. First, through the development of a computer program, the study demonstrates how to estimate the direct fiscal impact on a local community's property tax revenue from changes in the width of vegetated buffer zones around wetlands. The program utilizes the new wetlands data developed as part of the Rhode Island Geographic Information System (RIGIS). This data provides the most up-to-date, detailed and complete representation of fresh water and coastal wetlands within the state of Rhode Island. This data is integrated with existing tax assessor's records via digitized parcel maps using ESRI Inc., ARC/INFO software. The program (macro) enables the user to be shielded from the underlying complexities of the program thereby minimizing keyboard entry and ensuring the integrity of the results.

Second, the study shows the application of the program to a pilot study area in the Town of New Shoreham, Rhode Island. This community is currently the only one in the State that has complete digital parcel map coverage and a tax roll compatiable with the ARC/INFO software. An island-wide analysis is beyond the scope of this research, although could be readily done using the program.

This research is significant since there has been very little fiscal or economic analysis undertaken on the impact of vegetated buffers on property taxes. There has been much research on the technical and scientific justification necessary to implement a policy to increase 
buffer zones widths to insure the protection of an area's natural resources. Currently, research is being done in Rhode Island on these vegetated buffers at The University of Rhode Island (Groffman, et al.), Roger Williams College, and The Land Management Project (sponsored by the U.S. Environmental Protection Agency and R.I. Department of Environmental Management). Additionally IEP Inc., Environmental Scientists, Planners \& Engineers are developing a Guidance Manual on buffers to provide state and local planners with a systematic and consistent method for delineating site-specific buffer widths for the protection of wetlands and other wetland resources. Among their recommendations is that a costbenefit analysis be performed to assess the impact of increasing buffer widths around wetlands and other water resources (Roman 1990). The development of this macro and its application will contribute to an overall understanding of the fiscal impacts of such environmental regulations and the use of GIS at the municipal level for spatial and fiscal analyses.

The following chapters include discussions on background information For the development of the macro (Chapter 2), methodology of the macro including a flow chart (Chapter 3), description of the pilot study area and data (Chapter 4), results of the pilot study area analysis (Chapter 5) and conclusions (Chapter 6). 


\section{H A P E R T W O}

\section{BACKGROUND TO MACRO DEVELOPMENT}

This chapter establishes a framework by setting out the technical and scientific background to the development of the macro. The capabilities of the macro are detailed, data requirements listed, major concepts explained and terminology defined.

\section{Major Fiscal Impact Analysis Issues Addressed}

The fiscal impact analysis macro has the capabilities to address the following major issues:

1. The direct fiscal impact on property tax revenues of updating a local community's tax assessor's database for "Waste Acreage" using fresh water wetlands from the RIGIS wetlands coverage. "Waste Acreage" is defined to exclude the $50^{\prime}$ buffer areas around wetlands regulated by the DEM. The maximum, average and minimum tax loss caused by the spatial error of the wetlands data can be considered.

2. The direct fiscal impact on property tax revenues of updating a local community's tax assessor's database for "Waste Acreage" using the fresh water wetlands from the RIGIS wetlands coverage. "Waste Acreage" is defined to include the $50^{\prime}$ buffer areas around wetlands regulated by the DEM. The maximum, average and minimum tax loss caused by the spatial error of the wetlands data can be considered.

3. The direct fiscal impact on property tax revenues of increasing the vegetated buffer width around fresh water wetlands regulated by the DEM. An up-dated tax assessor's database would be used that considers wetland buffers as "Waste Acreage" (generated in 2. 
above). Scenarios for buffer widths greater than $50^{\prime}$ can be developed, with the width at the discretion of the operator. Maximum, average and minimum tax loss caused by the spatial error of the wetlands data can also be considered.

The macro enables a cormunity to assess the impacts of changing its property tax rate and the assessed value of "Waste Acreage". The collective impact of community-wide changes can be readily determined, as well as the effects upon individual lots (and property owners) analyzed.

\section{Data Requirements}

To develop and operate this macro it is essential that the following data be available for use with a geographic information system:

- digital plat maps of the municipality or study area with polygon attribute information (.PAT) containing area, perimeter and plat/lot reference for each lot.

- digital coverage of RIGIS wetlands for study area with a .PAT file specifying area, perimeter and wetlands type according to the U.S. Fish \& Wildlife Service Classification System, and

- an INFO data file of the study areas tax roll containing the plat/lot reference, assessed value of land and buildings, and total lot area with break-downs for usable and non-usable portions on a lot-by-lot basis.

\section{Fiscal Impact Analysis}

Fiscal impact analysis (FIA) is a technique to determine the impact of a proposed policy or development change on a local government's financial position. It does this in two ways, first by measuring the 
changes in assessed land values and then the change in property tax revenue. Changes in land values may change property tax revenues and therefore the fiscal flow, and with real property tax being the largest source of revenue in most communities any negative changes can be crucial in the supply of services.

The macro deals with the direct fiscal impacts on revenues associated with real property wealth, utilizing existing local data sources and revenue calculation methods. Secondary or indirect impacts are not analyzed through the macro. These include such effects as the shifting pattern of land use development, windfall to adjacent properties, raising the development pressure on vacant land, increasing the economic value of wetlands, changes in the character of a community, and raising the development pressure on vacant land that may be moderately environmentally sensitive or for slowing growth in a community. Although the significance of these indirect impacts have long been recognized, predicting and measuring these effects is difficult with any degree of confidence (Schaenman \& Muller, 1974). There is often the potential for the reoccurrence of effects and therefore the likelihood of doublecounting.

\section{Revenues Relating to Real Property}

Real property is usually taxed by local government, where in general, the same tax rate is applied to both residential and non-residential property. The revenues from real property (land and buildings) are generally the major revenue source in a local community and so changing the property tax rate has simple and straightforward fiscal effects. A tax rate change affects revenues received meaning that previously 
projected revenue estimates for the community's budget would have to be adjusted. A change in the value of property also has fiscal effects, since the property tax rate is computed by dividing the total tax levy by the aggregrate assessed valuation of property in the community.

Property tax revenue (PTR) is dependent on 3 different factors: the true value of real property (MV), the tax (or millage) rate, and the collection rate (equalization ratio). The true value of real property is the market value (MV), calculated by dividing the assessed value $(A V)$ by the equalization ratio. The equalization ratio is the ratio of assessed to true value of real property. It is based on the actual ratio of assessed value to sales price of properties sold in the recent sampling period. The relationship between PTR and these 3 variables is expressed as follows:

$$
\mathrm{PTR}=(\mathrm{MV})(\mathrm{TAX} \mathrm{RATE})(\mathrm{AV} / \mathrm{MV})
$$

or simplified as,

$$
\mathrm{PTR}=(\mathrm{AV})(\mathrm{TAX} \text { RATE })
$$

For example, the Town of New Shoreham's tax rate for 1988 was $\$ 14.12$ per thousand based on $80 \%$ of the true value of real property. Therefore an owner with property with an assessed value of $\$ 100,000$ would expect to pay $\$ 1412.00$ in real property tax, in addition to other fees such as sewer, trash collection.

\section{Land Value Assessment}

The economic value of land is directly proportional to the intensity of the use to which it can be put. Changes in environmental regulations, 
such as the width of buffers around wetlands will impact land values. Windfalls to adjoining properties will most likely occur since the land is undevelopable and provides increased areas of open space in the neighborhood. In certain areas the intensity of future, but not present, use will be reduced, while in other areas the future intensity will be increased. Not only are individual landowners affected by changes in land prices, but since comparable sales often form the basis for assessments, the ratable base (and hence the tax rate) of a local community will also be impacted.

In the Town of New Shoreham each lot of record was appraised in 1982 based on sales prices over previous years and comparable sales in the neighborhood. The assessed value of land and buildings are adjusted annually from this 1982 assessment and recorded in the tax assessor's database. The next reassessment is due in 1992.

The tax assessor's database is a detailed record of each lot of record in the Town and includes information on ownership, land use, acreage and other pertinent data. Of particular interest are the breakdowns of each lot into usable and non-usable areas. Usable land is termed both "Excess Acreage" and "Lot Size" and is all the land considered to be developable according to the Town's Zoning Ordinance definition of "Developable Land". To compute the total usable area of a . lot from the database it is necessary to add the "Excess Acreage" figure to the "Lot Size" figure (converted to acres). Lot Size is the maximum area of a buildable lot that could be created under the current Subdivision Regulations. (These figures in the 1987 database are of little use now since minimum subdivision size has been increased to 3 
acres and therefore were not used in developing the macro or applying it to the pilot study area).

The expression "Excess Acreage" (EA) used in the macro and in this study is defined as the total usable area of a lot of record and includes all the area of a lot deemed non-usable or unbuildable through development constraints such as wetlands, bluffs or beaches. These areas in the Town are valued at less than 1 cent per square foot. Inspection of the Tax Roll in 1987 and 1989 revealed that these waste areas are valued in both instances at $\$ 400$ per acre, however the value of "Excess Acreage" increased $8 \%$ annually. The Town's current policy is the exclusion of the buffer areas around wetlands in the computation of "Developable Land" and "Waste Acreage" figures for taxation purposes.

\section{Developable Land}

Under RI General Law, Sections 2-1-18 et seq. fresh water wetlands are defined to include,

but not be limited to marshes; swamps; bogs; ponds; river and stream flood plains and banks; areas subject to flooding or storm flowage; emergent and submergent plant communities in any body of fresh water including rivers and stream and that area of land within fifty feet (50') of the edge of any bog, marsh, swamp, or pond.

According to the Fresh Water Wetlands Act definition, several wetland types are further defined. The definition includes deepwater areas and the 100-year flood plain as wetland. Minimum size limits are placed on ponds ( $1 / 4$ acre), marsh ( 1 acre), and swamp ( 3 acres). Under the definition of "river bank", all land within 100 feet of any flowing body of water less than 10 feet wide during normal flow and within 200 feet of 
any flowing body of water 10 feet or wider is protected as wetland.

This state law regulates the draining, filling, excavation, damming, diking or diversion of water to wetlands, placing of trash, garbage, sewage, highway runoff, drainage ditch effluents and other materials and effluents upon, change or otherwise alter the character of any fresh water wetland. These regulations also pertain to activities on uplands within $50^{\prime}$ of a wetland. Activities in rivers, on flood plains and river banks are regulated as fresh water wetlands by the RI Department of Environmental Management.

The Town's Zoning Ordinance Sections 202 (46), (61) and (90) regulate fresh water wetlands over 1000 square feet and defines them as:

$$
\begin{aligned}
& \text { having the characteristics set forth as defining .... } \\
& \text { (swamps, marshes and ponds) .... in the wetlands } \\
& \text { regulations of the Department of Environmental Management. }
\end{aligned}
$$

Local regulations may impose greater restrictions than state or federal laws or regulations, however they may not be less. The Ordinance further specifies that:

Agricultural uses shall retain a buffer of natural growth at least fifty (50) feet wide around all wetlands and water bodies except that access ways to the water may remain cleared.

Section 503, B (3).

In other words, buffers are required around all fresh water wetlands in the Town which meet the Fresh Water Wetlands Act definition and where agricultural uses are adjacent to fresh water wetlands 1000 square feet or more. The fifty foot buffer is wetland, and technically should be included when calculating the developable portion of a lot. 
Section 202 (20) of the Ordinance defines "Developable Land" as:

The area of a lot or land parcel on which development may occur, determined by subtracting from the total area the following:

(a) All beaches, bluff, dunes, ponds, wetlands and streams.

(b) All land within easements serving other lots, including but not limited to sewage disposal systems, or wells, but not including scenic and conservation easements, or easements for access.

(c) For Residential A Zone and Residential B Zone only - 158 of the remaining area of the parcel as an allowance for roads and parking, whether or not the actual area devoted to roads and parking is greater or less than $15 \%$.

The term "Development" is defined under section 202 (21) as:

Any man-made change to improved or unimproved property, including but not limited to buildings or other structures, mining, dredging, filling, grading, paving, excavation or drilling purposes.

Use of GIS For Fiscal Impact Analysis

A geographic information system (GIS) enables the input, output, storage and analysis of spatially referenced data. Its ability to manage and manipulate large amounts of spatial and tabular data make it particularly valuable for fiscal impact analysis. It provides planners and decision-makers with the capability to address complex issues in entirely new ways.

Not only are digital spatial data vital for a GIS, but a relational database structure as well. This is the key for performing FIA on a GIS. The relational database allows attribute information to be combined as the geographic features from two separate maps or data files are covered. (Attribute information is that information associated with a digitized feature, such as the area, perimeter, zoning and plat/lot reference for 
digital plat maps). Information about ownership and the assessed value is stored in a separate data file which is accessed through a common item in each, typically the plat/lot code. When two coverages are overlayed and joined the attributes for all the new areas from both coverages are maintained. The ESRI ARC/INFO geographic information systems software has this data structure, and also enables the buffering of features, such as wetlands, necessary for this fiscal impact analysis.

\section{Spatial Error and The RIGIS Wetlands}

The Rhode Island Geographic Information System (RIGIS) is a database of map information for the state of Rhode Island. It is an attempt to make geographic information an integral part in the management and protection of the State's natural resources. Currently it houses statewide coverages for wetlands, soils, ground water, surface water, and cadastral coverages of roads, railways and open space areas. It is this wetlands coverage that is used in the FIA macro.

The RIGIS wetlands represent a comprehensive and detailed representation of fresh water and coastal wetlands in the state. They were interpolated from 1:24,000 black and white aerial photographs flown in 1988, and then digitized. The wetland/upland boundary was delineated on the photography for wetlands at least one quarter $(1 / 4)$ acre in size. The wetland units are classified into one of sixteen types according to the U.S. Fish \& Wildlife Service classification system. Data were field checked (MacLachlan, 1990).

When any thematic or topographic map is produced in digital form it contains errors that should be quantified before the map can be 
used with confidence. This is spatial error and for the RIGIS wetland coverage is the difference between the digitized versions of the mapped wetlands and their true location on the ground.

Spatial error may be attributed to a number of sources. Generally the source maps have not been compiled and produced with future computer integration in mind: the maps are at different scales, on different map projections and produced at different times. Maps and plans are produced for a variety of purposes, by different authorities, and with differing levels of accuracy. The topological manifestation of merging data sets entered into a GIS create a dilema for planners, cartographers and decision-makers alike.

Spatial error may be attributed, not only to those errors present in the source document and automation process but from the dynamic nature of cartographic features themselves. On a wetlands map these errors are due to the inherent error in the wetland feature itself.

A wetlands map is an approximation of the true surface conditions and its accuracy is limited by several factors, including the wetlands classification scheme, quality of imagery, minimum mapping unit and expertise of the photointerpreters. Wetlands vary along a continuum and are not always composed of discrete natural regions. The boundaries between regions may reflect gradual changes and often tend to be indistinct and arbitrary in nature. Therefore, the line represented on a wetlands map may actually represent a zone of transition. This situation would less likely occur when there is a defined edge to the feature, such as a wetland abutting a road or characterized by open water. 
Graduate researchers at The University of Rhode Island have done some preliminary testing on the accuracy of the RIGIS wetlands and the usefulness of this data for parcel-based decision-making (Hooker \& Hutchinson, 1989). This research concluded that the true location of a "discrete" wetland feature is on average \pm 40 ground feet from the mapped line. (Discrete wetlands were those with non-tidal open water, which were the easiest for both the researchers and photointerpreters to accurately identify). This estimate of spatial error is used in the macro to estimate the maximum, average and minimum fiscal impacts expected, being the only estimate available at the time. If the error around a digitized feature is not taken into account the users could draw faulty conclusions from the use of this spatial information. 


\section{H A P T E R TH R E}

\section{MEHHODOLOGY OF MACRO OPERATION}

\section{Introduction}

The macro is compiled of three modules each with the ability to calculate what might be the best case, medium case, and worst case impact on the property tax base of local government. It uses a standard dialogue-based user interface, prompting for dialogue input from the terminal. This helps to speed up the running of the program by eliminating repetitive keyboard typing, as well as ensuring the integrity of the calculations.

Presented here is a step-by-step description of the general operations of the FIA macro. A flow chart has been included at the end of the chapter to allow an understanding of the full flow of operations available through the three modules and scenarios available for development.

\section{Prepare Data For Spatial Operations}

To ensure integrity of the original tax assessor's database the macro commences by making a direct copy of the INFO file of the tax assessor's database. To this data file two items are added called VALACRE and TAX-DUE to enable computations to be made using existing information in the database. Prompts request the entry of two numeric variables WAVAL and TAXRATE. At the terminal the user will see:

\footnotetext{
Please Enter Value of Waste Land Per Acre

Please Enter Tax Rate Per Thousand
} 
The responses given are used to calculate the assessed value per acre of "usable" land and the real property tax due on each lot. The item BIACRES is dropped from the data file, and a new "Excess Acreage" computed based on the areas from the digitized lot coverage. Value per acre and property tax due are calculated by the following formulae:

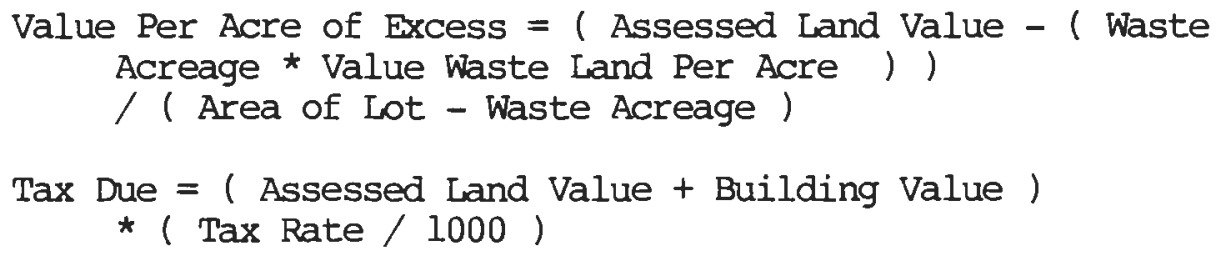

Two items, GIS-TAX-DUE and GIS-TAX-LOSS are added to the data file to enable the property tax that would be expected from the lots under the scenarios developed later to be stored.

\section{Select Fiscal Impact To Calculate}

To implement one of the three modules the user is prompted to interactively select the type of fiscal impact to be performed. At the terminal the following is displayed:

$\begin{array}{ll}\text { "Waste Acreage" Excludes Wetland Buffers } & -1 \\ \text { "Waste Acreage" Includes Wetland Buffers } & -2 \\ \text { Different Buffer Widths Around Wetlands } & -3 \\ \text { Quit and Exit } & -9\end{array}$

Please Enter One Digit

Modules 1 and 2 can be run in any order, however it is imperative that module 2 be run before module 3 . Property tax losses in module 3 relate to those property taxes that would be derived from an up-dated database where the 50 foot buffer is included as "Waste Acreage" (Module 2 Average Impact). 
Depending on the module selected a number of variables are set to pre-determined values. These variables enable different versions of the wetlands coverage to be used, different versions of the tax assessor's database accessed and a unique naming system to be developed for all the various coverages and INFO files created for any scenario. A response of either 1 or 2 directs the user straight to the next selection area - the amount of fiscal impact to be calculated. This allows the user to test for the implications of spatial error associated with the wetlands data. Average Impact assumes no spatial error, Maximum Impact assumes +40 feet, Minimum -40 feet. A response of 3 sets the third module in operation and immediately prompts the user for additional information concerning the scenario to be developed regarding buffer widths. At the terminal the following would be displayed:

Please Enter Buffer Width In Feet

Once a value is entered Flow is returned to that for Modules 1 and 2 where the user is requested to select the amount of fiscal impact (based on maximum, average and minimum spatial error) to be calculated. At the terminal the user would see:

Select Amount of Fiscal Impact To Calculate

$\begin{array}{ll}\text { Maximum Impact } & -3 \\ \text { Average Impact } & -2 \\ \text { Minimum Impact } & -1 \\ \text { Quit } & -0\end{array}$

Please Enter One Digit

Again depending upon the user's response flow is directed through numerous loops, directives and spatial operations where such operations 
as buffer, line-in-polygon, and polygon overlay are performed.

\section{Perform Spatial Operations}

The process of operation differs according to each module but the general methodology approximates that incorporated in module 1 . For this reason the only methodology detailed here is for the determination of the maximum, average and minimum impacts where wetlands are excluded from the

"Waste Acreage" estimates. The methodology for module 2 involves a certain amount of relating of data files and coverages to calculate new "Waste Acreage" estimates and would involve a somewhat more lengthy and complicated description. As noted earlier, a flow chart of the operations for modules 1,2 and 3 is included later in this chapter.

\section{Maximum Impact}

For the development of this scenario for module 1 all of the fresh water wetlands from the RIGIS coverage are utilized and buffered at a distance of 12.192 metres (40 feet). The BUFFER comand generates polygons around coverage features at a prescribed distance and computes the new area of the polygon (wetland + buffer). This coverage is then spatially overlayed with the lots coverage using the cormand UNION. This command computes the geometric intersection of 2 polygon coverages, so that all the polygons from both coverages are split at their intersections and preserved in the output coverage. The JOIN in UNION enables all the .PAT items from both coverages to be kept and appear in the output coverages.

Those portions of lots which contain the buffered wetlands polygon are RESELECTEd from the UNIONed coverage and RELATEd to the tax 
assessor's database. This temporary relating of data file and polygon coverage is done by having a common item in each - in this case the Plat/Lot/SubLot code. The new "Waste Acreage" is computed by adding the related area (converted to acres) to the tax assessor's database. A new figure for "Excess Acreage" is computed based on the revised "Waste Acreage" area before a new total assessed Land Value (LV) for each lot is computed using the value per acre of "Excess Acreage" under the current situation and the value of "Waste Acreage". The real property tax generated from these lots is then calculated and the difference between the existing Tax Due and the present scenario is computed as the Tax Loss and displayed at the terminal. At the terminal the user would see

Estimated Maximum Tax Loss When

"Waste Acreage" Excludes Wetland Buffers

\section{$\$ \ldots \ldots$}

At the completion of this scenario flow is directed to the area in the program which requests 'Selection of Fiscal Impact To Calculate'. If the user desired to develop additional scenarios for module 1 a response of 1 would simply be given. This directs a prompt to the screen again for the 'Amount of Fiscal Impact To Calculate'. For descriptive purposes the methodology for the Average Impact is described.

\section{Average Impact}

When this scenario is developed for module 1 no BUFFERing of the wetlands coverage is required since no spatial error is assumed to be associated with the data. The wetland coverage is simply UNIONed with the lots coverage and the polygons with wetlands RETATEd to the tax 
assessor's database and new areas for Waste and Excess computed and values for Land Value, GIS Tax Due and GIS Tax Loss computed. The total loss in property tax for the study area would be displayed at the terminal with the following message:

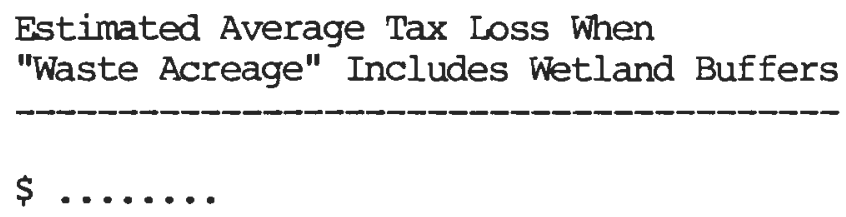

Minimum Impact

When this scenario is developed for module 1 the wetlands are BUFFERed by LINE rather than by POLY at the distance 12.192 meters ( 40 feet). This treats the wetland polygon as a line and creates an inner and outer perimeter of the buffer. The areas inside and outside of the buffer are flagged automatically; those polygons that represent areas outside of a wetland or its buffer zone are listed as (1) in the item INSIDE and those within a buffer zone (100). This enables the inner perimeter of the buffer area to be RESELECTed and UNIONed with the lots coverage. Again the polygon coverage is RELATEd to the tax assessor's database and areas and values calculated. The total loss in real property tax for the study area would be displayed at the terminal with the following message:

Estimated Minimum Tax Loss When

"Waste Acreage" Includes Wetland Buffers

$\$$

Production of Final Maps and Tabular Reports of the Results Summary maps and tabular reports can be readily generated after running 
the FIA macro. Several examples of maps are included in the following chapter, which although were produced outside of the macro, they use the coverages and data file produced by it. The production of maps and tabular reports could be included in the FIA macro though were beyond the scope of this research project.

\section{Flow Chart of Macro Operation}

To assist in an understanding of the flow of operations of the FIA macro a flow chart is presented here as Figure 2. A flow chart is simply a graphic representation of the logic inherent in the program (Brail, 1987). Flow charts use a set of symbols to indicate the various program steps and are shown in Figure 1. The general processing symbol is used predominately for calculations. The decision symbol represents options for a change in flow of operations. The input-output symbol represents interactions with the keyboard, printer or plotter. The entry or exit symbols acts as a program beginning or end symbol.

\section{Figure $1 \quad$ Components of a Flow Chart}

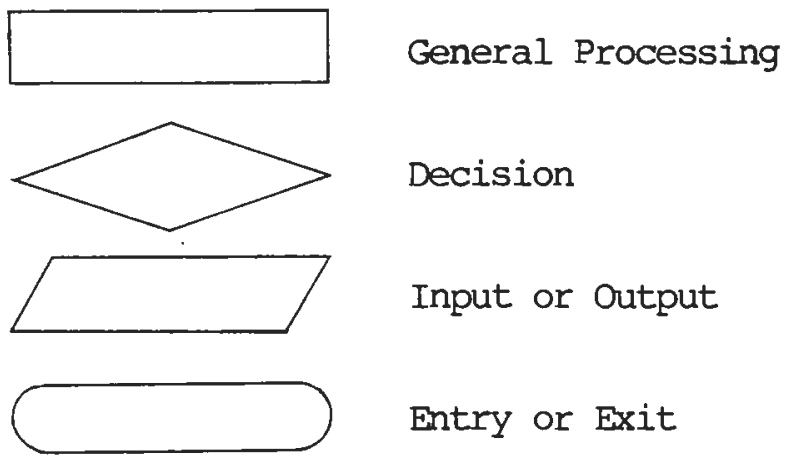


Hgure 2 Now Gart of res moro

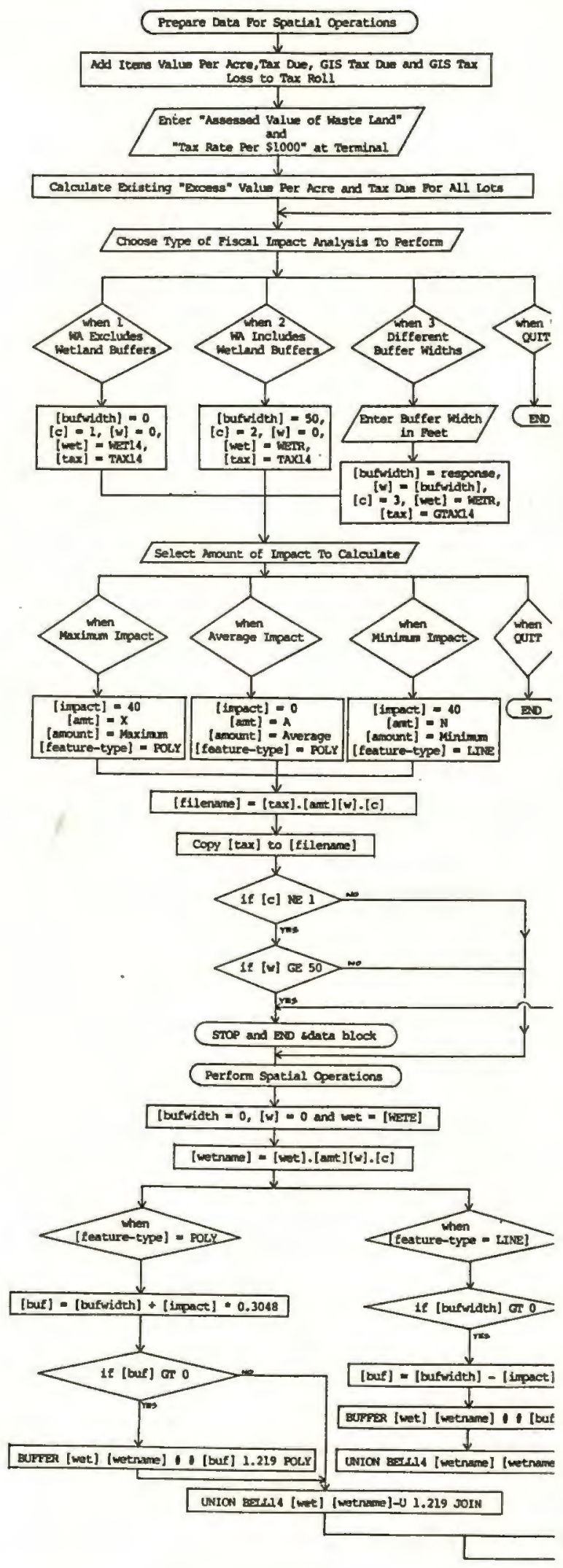




\section{H A T E R FOU R}

\section{PILOT STUDY AREA AND DATA}

\section{Pilot Study Area}

The pilot study area comprises 100 lots of record located in the southwest part of the Town of New Shoreham and encompasses all that lots shown on Tax Assessor's Plat 14. The approximately 340 acre area is bounded on the south and west by the Atlantic Ocean where bluffs and a rocky shoreline form the coastal edge. A dozen or so fresh water wetlands and ponds lie within this area including Warden's Pond, Cooneymus Swamp and part of Franklin's Swarmp. The size of lots range from under $1 / 4$ acre to over 40 acres, although average size is 3.42 acres. At least 40 percent of the lots are undeveloped (from 1987 tax assessor's database) including the protected open space areas of the Audubon Society of Rhode Island (part of Lewis-Dickens Farm) and the Block Island Conservancy. Predominant land use is residential comprising single-family residences and summer homes. Several properties are used for agricultural purposes.

Plat 14 provides a good representation of the wide variety of lot sizes, wetlands and land values which can be found in the Town. Further, when the tax assessor's plats were digitized by the Block Island Land Trust this plat was least affected by the transformation process (Thompson, 1989). This means that the quality of the digitized version of the lots is good in terms of area, shape and absolute location. Figure 3 shows the location of the pilot study area in the Town of New Shoreham. Figure 4 is the 1985 aerial photograph of the study area. 


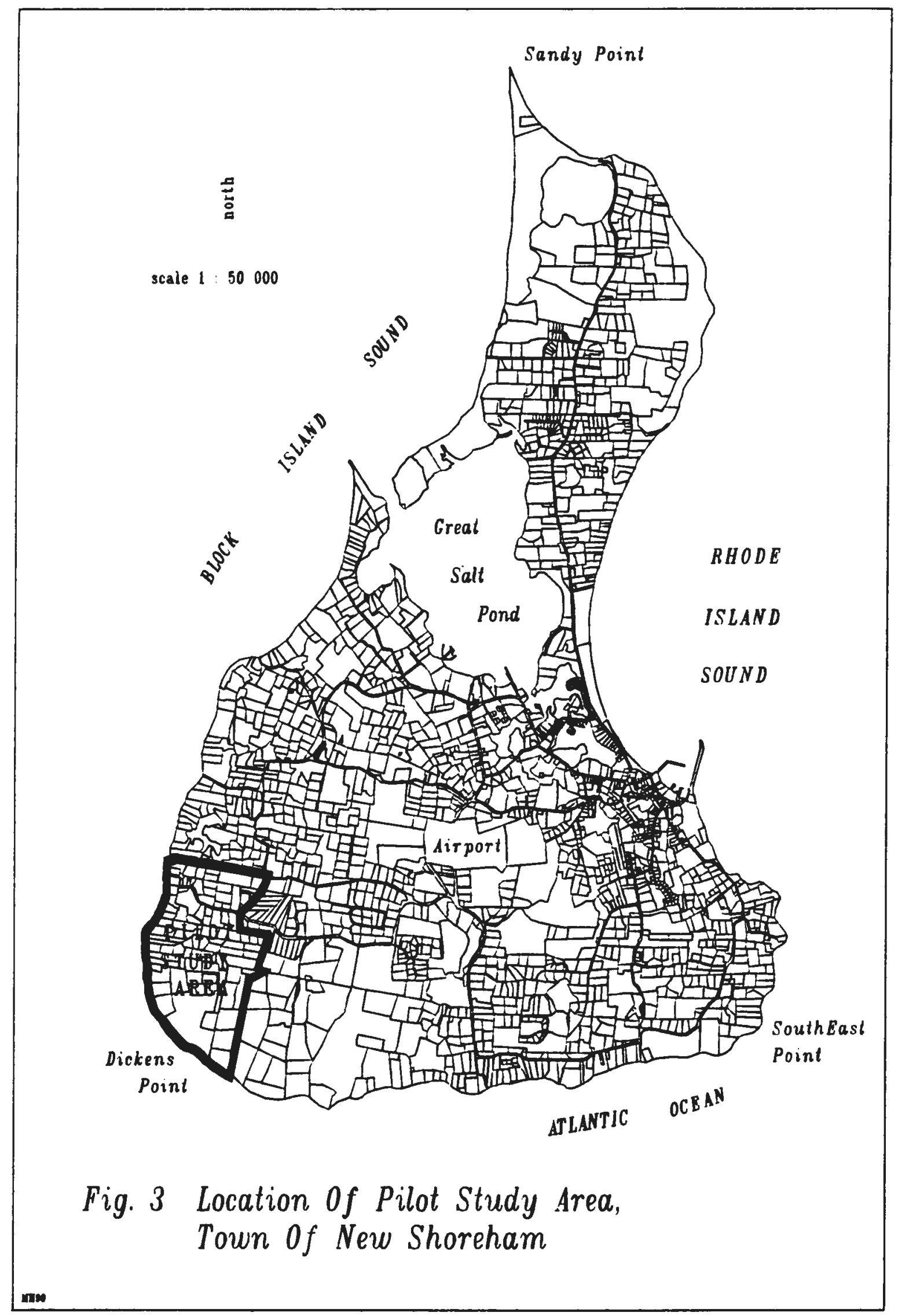




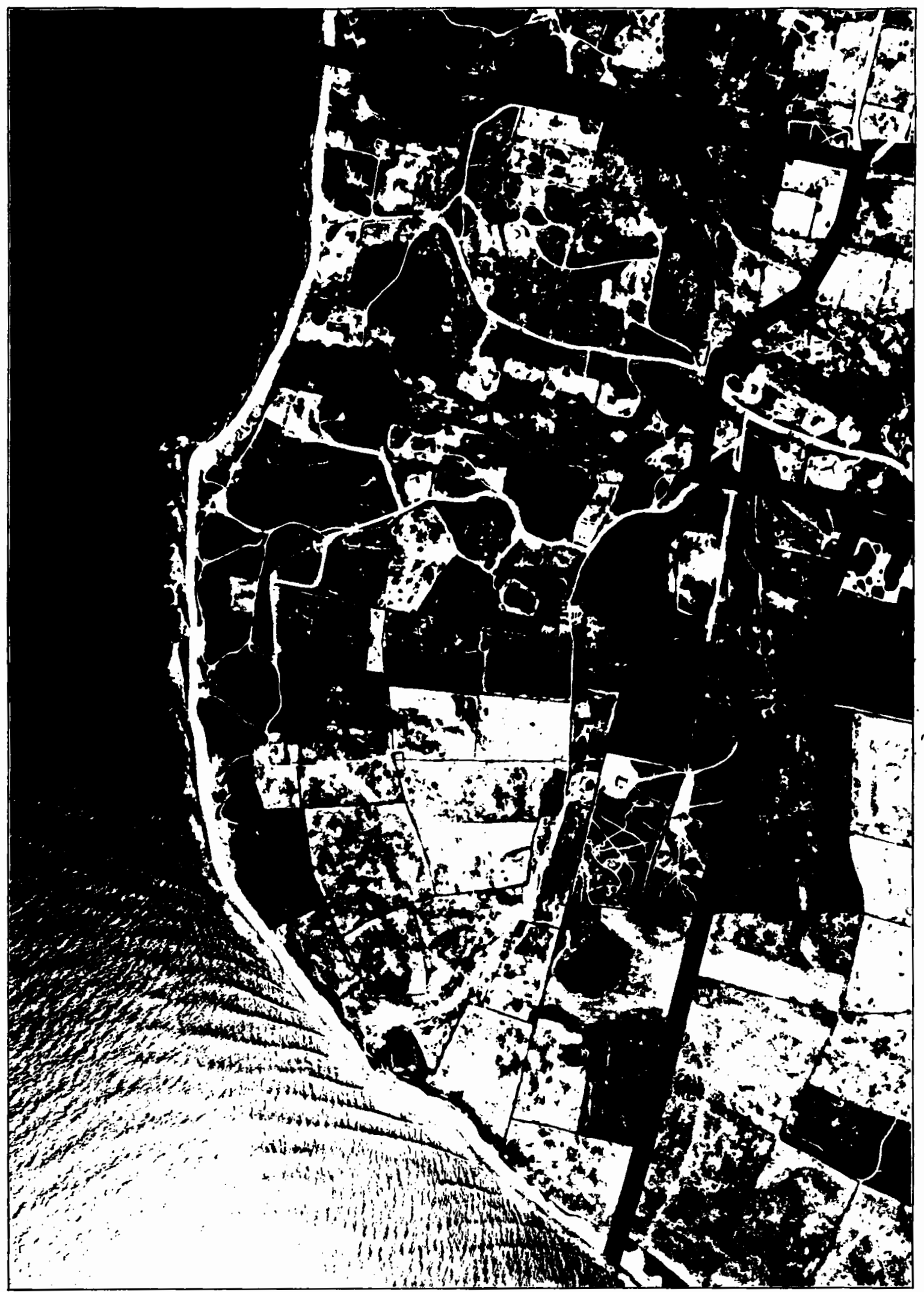

F1g. 4 Pllot study Area

Source: ADR Associates,

3/25/85, approx scale 1:10 000 
Description and Preparation of Pilot Study Area Data

The following coverages and INFO data files are used for the pilot study area analysis:

1. Lot Maps

(a) Source: The Town of New Shoreham has complete digital lot coverage as a result of a noteworthy effort by the Block Island Land Trust in 1988-89. The coverage called BELL shows all lot lines, roads, ponds and coastlines delineated on the tax assessor's maps and updated to include new roads, subdivisions and consolidations to February 1990. This digital coverage provides the vital link between the tax assessor's database through the plat/lot reference.

(b) Preparation: The lots for the pilot study area were CLIPped to the outside boundary of Plat Map 14 from the island-wide coverage BELL, with the out-coverage named BELL14. Figure 5 shows the digitized lot coverage BELL14. The lots are identified by a unique seven digit reference called CODE. A CODE of 1404201 represents that lots as shown on Plat 14, Lot 42 , SubLot 1 .

\section{Wetlands}

(a) Source: The RIGIS wetlands coverage provides the most up-to-date and comprehensive representation of fresh water and coastal wetlands in the State. They were interpolated from 1:24000 black and white aerial photography flown in 1988 and digitized by IEP Inc. of Massachusetts. Wetlands are classified into 16 different types according to the U.S. Fish \& Wildlife Service systen.

(b) Preparation: Wetlands within the pilot study area were CLIPped to 
the outside boundary of Plat Map 14 from the island-wide coverage WET. The 35.45 acres of fresh water wetlands were RESELECTed and saved to a coverage named WET14. This coverage is used when analyzing the impacts of up-dating the tax roll using the RIGIS wetlands and is graphically shown as Figure 5. Coastal wetlands within the pilot study area generally constitute rocky shoreline and approximate the bluff areas indicated in the tax roll as "Waste". They are therefore not used in updating the tax roll.

From the coverage WETl4 above, those fresh water wetlands which are subject to a 50 foot buffer by the DEM were identified. These wetlands satisfy the minimum size criteria placed on ponds (one quarter acre), marshes (one acre), and swamps (three acres). The cormon boundaries between fresh water wetlands of similar type (but different CODE) were removed. For example the boundary between two types of swamps were DISSOLVEd and the areas consolidated into one wetland polygon and duplicate LABEL points DELETEd. Wetlands were then RESELECTed based on the DEM minimum size criteria and saved to a new coverage called WETR. The coverage WETR was then laid over coverage WETl4 to identify any wetland polygons that failed the DEM criteria, yet had a common boundary with a regulated wetland. When this occurred the arc(s) between the two polygons was DELETEd and the contiguous polygon used to up-date the WETR coverage. This ensured that any BUFFERing of wetlands would be around the entire wetland area. Figure 5 shows the 30.36 acres of fresh water wetland called WETR coverage.

Those fresh water wetlands which are not subject to the 50 foot buffer requirement are saved to a coverage called WETE (5.09 acres). 


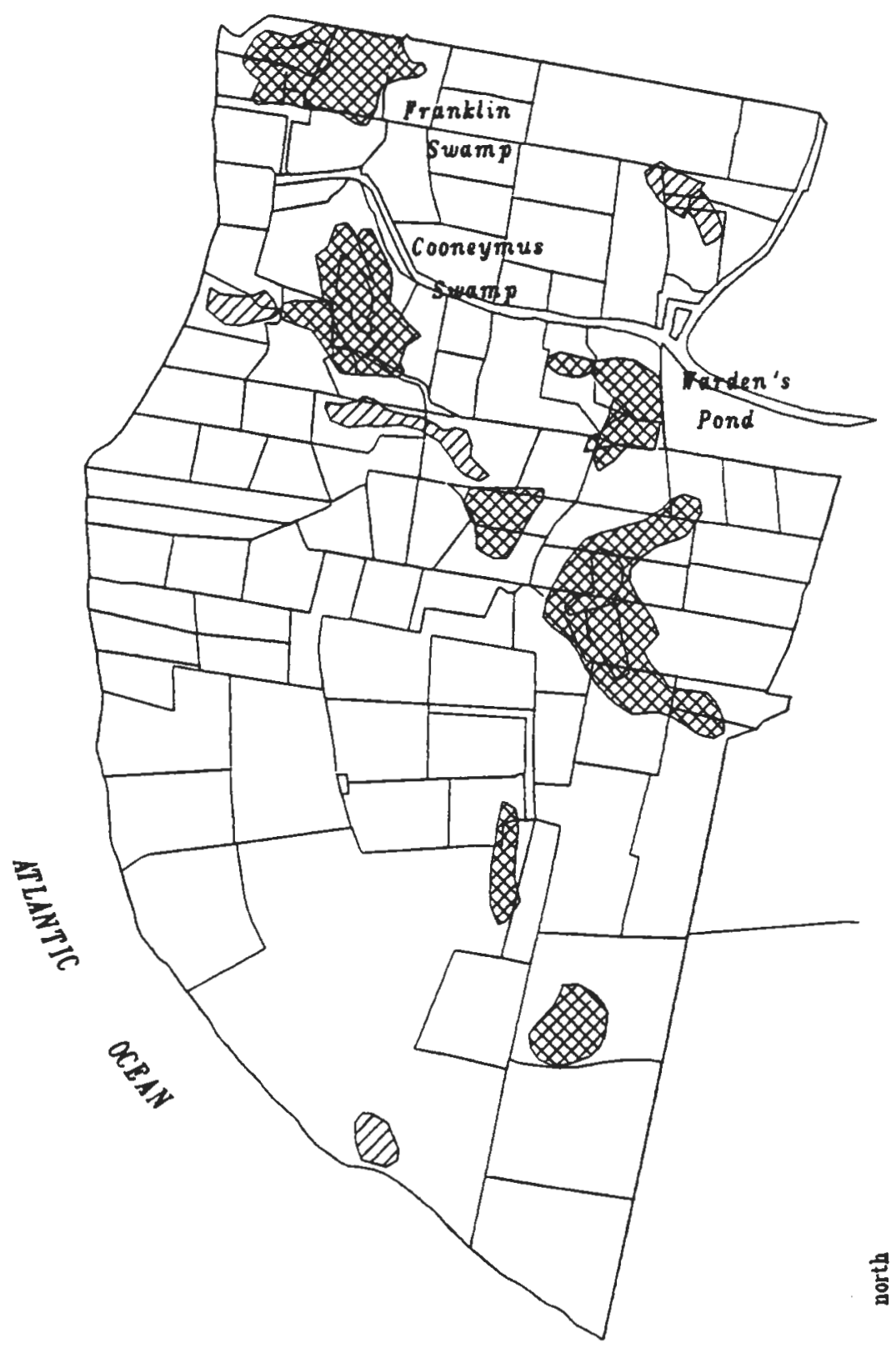

ENIII

Lots (BELL14 Coverage)

scale 1:12 000

Fresh Mater Wetlands (WET14 Coverage)

Wetlands Subject To Buffers (TETR Coverage)

Fig. 5 Fresh Water Wetlands In Pilot Study Area Source: RIGIS and Town of New Shorehan GIS 
These wetlands are used in Module 2 and 3 only, in conjunction with the WETR coverage.

\section{Tax Assessor's Database}

(a) Source: The 1987 tax assessor's database provides the necessary property data for use with the macro. At the time of this analysis it was the most recent database available for use with the GIS, however the 1988 database will shortly be available. If the Town were to perform an island-wide fiscal impact analysis for up-dating the database, this database should be substituted the 1987 version.

(b) Preparation: The records pertaining to the pilot study area (Plat 14) were RESELECTed from the island-wide data file TAX-DATA to TAXDATA14. Data required for use in the analysis were pulled using the command PULLITEM and are as follows:

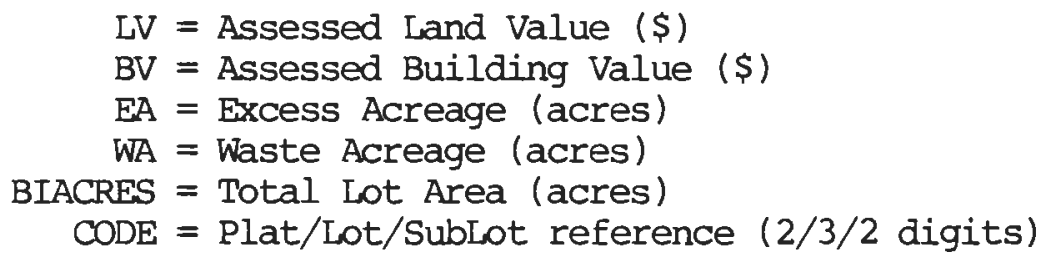

From the coverage BELCl4 the polygon attribute information of the lot area was brought into the data file TAX-DATAl4 and the item was called ACRES. It is this total lot area that is used in the operation of the macro.

\section{Sumary}

This chapter described the pilot study area, and the necessary preparation of the digital data before the FIA macro could be applied. The following chapter explains the reasoning behind the introduction of 
ACRES to the database and the results derived from the application of the macro to the pilot study area. 


\section{H P T E R I V E}

\section{PILOT STUDY AREA ANALYSIS}

The macro was run for all three modules; modules $I$ and 2 also tested for the maximum, average and minimum error, while for module 3 a total of three scenarios were developed based on increasing the vegetated buffer strip around the fresh water wetlands to 100, 200 and 300 feet. In all 9 scenarios were developed which took about 8 hours to run on The University of Rhode Island's Prime Computer. Processing on a PCworkstation should reduce the processing time needed. The Value of Waste Land per acre was entered as $\$ 400$ and the Tax Rate per thousand as $\$ 14.12$ (1987 tax rate). The results of the pilot study area application are presented and discussed here in this chapter.

\section{Use Of RIGIS Wetlands For Verification Of Waste Acreage Estimates}

Within the pilot study area "Waste Acreage" estimates recorded in the 1987 tax assessor's database are severely incomplete - confirming Town officials' expectations. In all cases when "Waste Acreage" was greater than zero in the database it would specifically be for that portion of the lot defined and delineated as "bank" (bluff/cliff areas) on the tax assessor's plats. Although wetlands (ponds, swamps and marshes) are delineated on these plats and are computed as part of the total square footage when determining the actual size of a platted lot (Ordinance, Section 202 (41)), the Engineers who produced these maps did not compute the area of wetland on each lot and hence this data was not readily available for entering in the database.

Table 1 compares the total area of wetlands from three different 
sources. The RIGIS wetlands coverage computes the most land area classified as wetland, at least 1008 more than is graphically represented on the tax assessor's plat and over 38 times that listed in the database.

Table 1 Comparison of Wetland Areas From Different Sources, Plat 14, Town of New Shoreham

\begin{tabular}{lc} 
Source & Area (acres) \\
\hline \hline 1987 Tax Roll & 0.00 \\
Tax Assessor's Plat & 18.85 \\
RIGIS Wetlands (coastal and Eresh water) & 38.50 \\
\hline
\end{tabular}

1 All of the 10.31 acres of "Waste" listed in the database were bluffs (the "bank" areas on the plat), not wetlands.

2 Calculated by grid square method.

3 Source WET14-TOTAL: coastal 3.05 acres, fresh water 35.45 acres.

Overlaying the lots coverage BELLl4 with the wetlands coverage WET14-TOTAL revealed a discrepancy over the mapped location of the coastline. This occurred most noticeably along the western edge which is subject to much erosion from wind and water. This obviously affects the accuracy of the "bank" areas since the "bank" is meant to correlate with the bluff/cliff areas for ocean-front lots. For this research they have however deemed to be a fair representaion, yet a more accurate estimate should be made.

Clarification and adjustment of these areas could be done from other digital coverages in the Town's GIS or from aerial or field surveys. Digitizing from up-to-date orthophotograph mylars would also be an appropriate method, however the most recent orthophotographs available 
for the Town are 1975 1:1320 scale U.S.G.S. mylar quads held by the USDA Soil Conservation Service. (Orthophotographs are photomaps prepared from a perspective aerial photograph in which the displacements of images due to tilt and relief have been removed, making them suitable for digitizing directly from). A clear definition of what defines the coastline should be made based on the purpose it will be put in the GIS; definitions could use the mean high water mark, edge of beach vegetation or other shoreline features.

\section{Wetland Buffers Excluded or Included From Waste Acreage Calculations}

Updating the tax assessor's database from the RIGIS wetlands data will have fiscal implications for the Town. The magnitude of that impact will depend, not only upon the interpretation of "Developable Land" used, but additionally by the size and configuration of the lots, the area, shape and frequency of the wetlands, topography, land uses, and the existing assessed land values. The variable nature of land values for "Excess Acreage" in the pilot study area is shown in Figure 6 - the higher priced land is generally along the western coast where lot size is smaller (average 2 acre). Table 2 summarizes the effects of introducing the RIGIS wetlands and the two interpretations of "Developable Land" for the pilot study area.

Use of the Town's present interpretation of "Developable Land" (buffer area's excluded) and the new wetlands data to determine "Waste Acreage", a decrease in property tax revenue from Plat 14 would result. It would be expected that the total assessed land value would decrease from $\$ 6,334,350.00$ to $\$ 5,816,879.00$, or 8.068 . This would cause a property tax loss of $5.77 \%$ or $\$ 7,306.69$. Of the 100 lots in Plat 14 it 


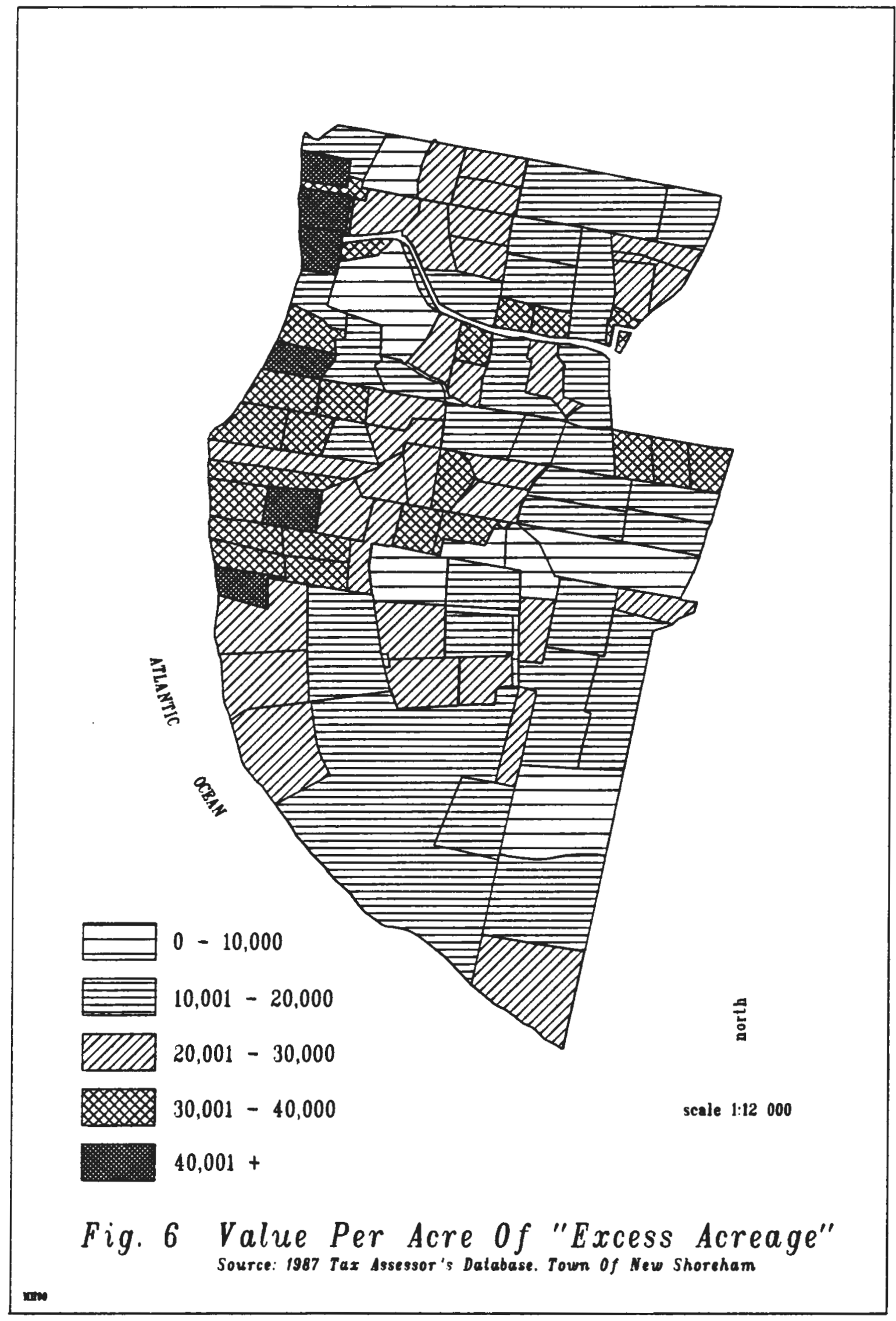


could be expected that 348 of them would have a lower tax due. Figure 7 shows the distribution of property tax loss in the pilot study area.

Alternatively when the technically correct interpretation of the term wetlands in used to include the buffer areas around wetlands, the fiscal impacts are greater. (Floodplains and stream buffers are not considered in this analysis however the impacts of including them could also be of much significance). This is because the additional area of land taken up by the buffers draws directly upon the limited supply of land that is now identified as usable land. The proportional value of this property is considerably higher and would provide a greater property tax return, but would be now diminshed. In light of the variable nature of land values for "Excess Acreage" in the pilot study area, certain lots would be more influenced by the introduction of the RIGIS wetlands and definition used by the municipal tax assessor for taxing purposes.

Table 2 Introduction of RIGIS Wetlands and Variation of Definition of "Waste Acreage" on 1987 Database, Plat 14, Town of New Shoreham

\begin{tabular}{|c|c|c|c|}
\hline Source/Data File & $\begin{array}{l}\text { Total Land Value } \\
\text { (mil. \$) }\end{array}$ & $\begin{array}{l}\text { Waste Area } \\
\text { (acres) }\end{array}$ & $\begin{array}{l}\text { Tax Due } \\
(\$)\end{array}$ \\
\hline Existing Database & 6.33 & 10.31 & $126,578.74$ \\
\hline $\begin{array}{l}\text { Wetland Buffer Excluded } \\
\text { From "Waste Acreage" }\end{array}$ & 5.82 & 45.68 & $119,272.05$ \\
\hline $\begin{array}{l}\text { Wetland Buffers Included } \\
\text { As "Waste Acreage" }\end{array}$ & 5.56 & 61.60 & $115,658.22$ \\
\hline
\end{tabular}

1 Assumes no spatial error of RIGIS wetlands. 
When wetlands that require a fifty foot buffer according to the DEM are included in the "Waste Acreage" estimates the total assessed value of property in Plat 14 would decrease by $\$ 772,234.00$ or $12.19 \%$. This would result in a loss in property tax of $\$ 10,903.94$ from the existing database records or 8.638 . Further 428 of the lots would be impacted by this definition and new data. Figure 8 shows the average tax loss on a lotby-lot basis when the $50^{\prime}$ wetland buffers are included in the "Waste Acreage" calculations.

The fiscal implications of the spatial error associated with the RIGIS wetlands is relevant, as can be seen from Table 3 . The tax loss from introducing the new data and excluding the buffer areas would range from a maximum loss of $\$ 11,584.77$ to a minimum of $\$ 2,563.08$. Average loss (where no spatial error is assumed) would be $\$ 7,306.69$. When the wetland buffer areas are included in the calculations the tax loss produced by the spatial error of the wetlands data would range from a high of $\$ 14,182.01$ to a low of $\$ 6,797.59$, with an average loss of $\$ 10,903.94$.

Table 3 Estimated Tax Losses Fran Spatial Error, Plat 14, Town of New Shoreham

\begin{tabular}{lrrr} 
& Max & \multicolumn{1}{c}{ Av } & \multicolumn{1}{c}{ Min } \\
\hline \hline $\begin{array}{l}\text { BUFFERS EXCLUDED } \\
\text { Waste Acreage }\end{array}$ & 63.58 & 45.68 & 22.49 \\
$\quad$ Tax LoSS & $11,584.77$ & $7,306.69$ & $2,563.08$ \\
\hline $\begin{array}{l}\text { BUFFERS INCLUDED } \\
\text { Waste Acreage }\end{array}$ & & & \\
Tax LosS & 76.79 & 61.55 & 49.82 \\
\hline
\end{tabular}




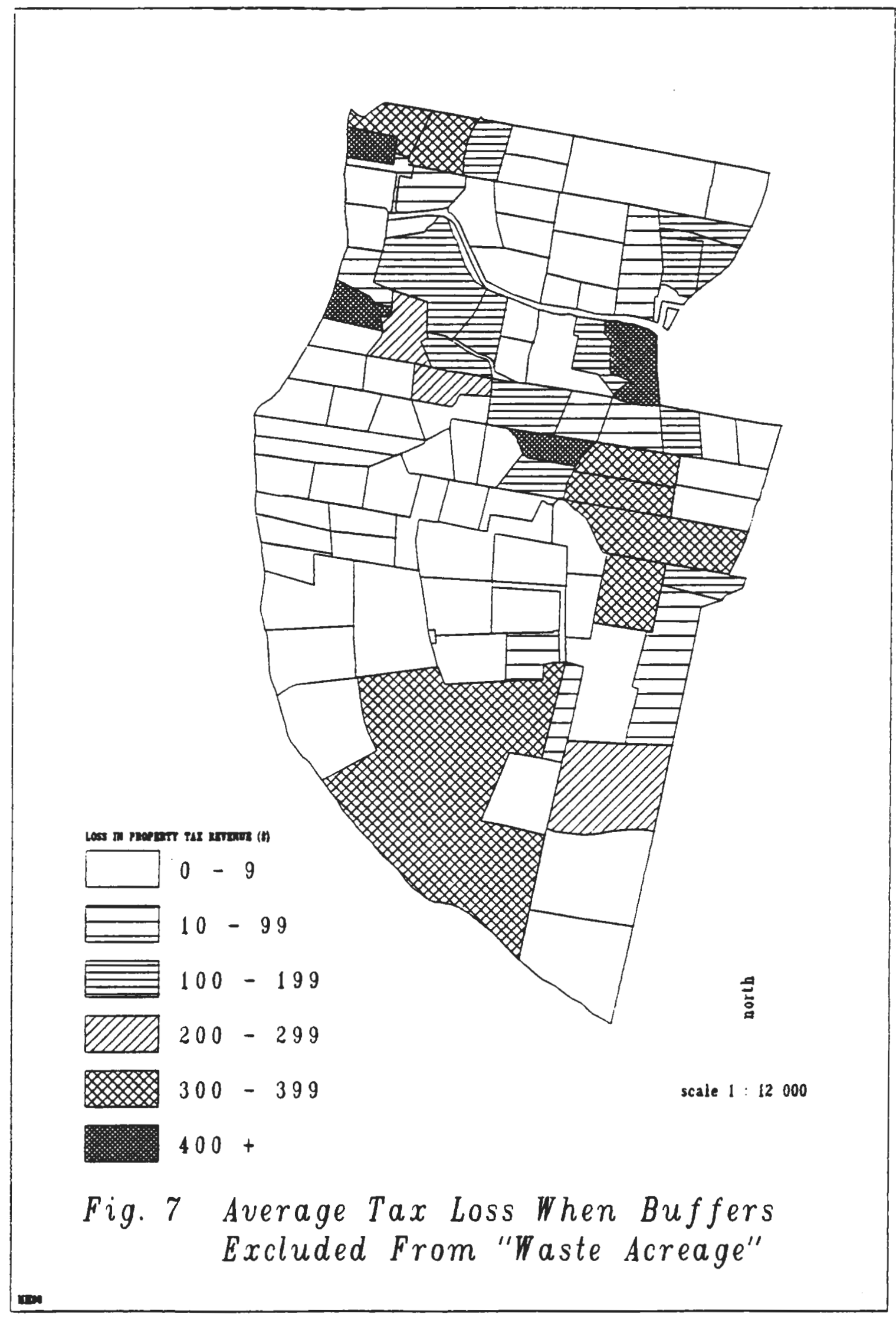




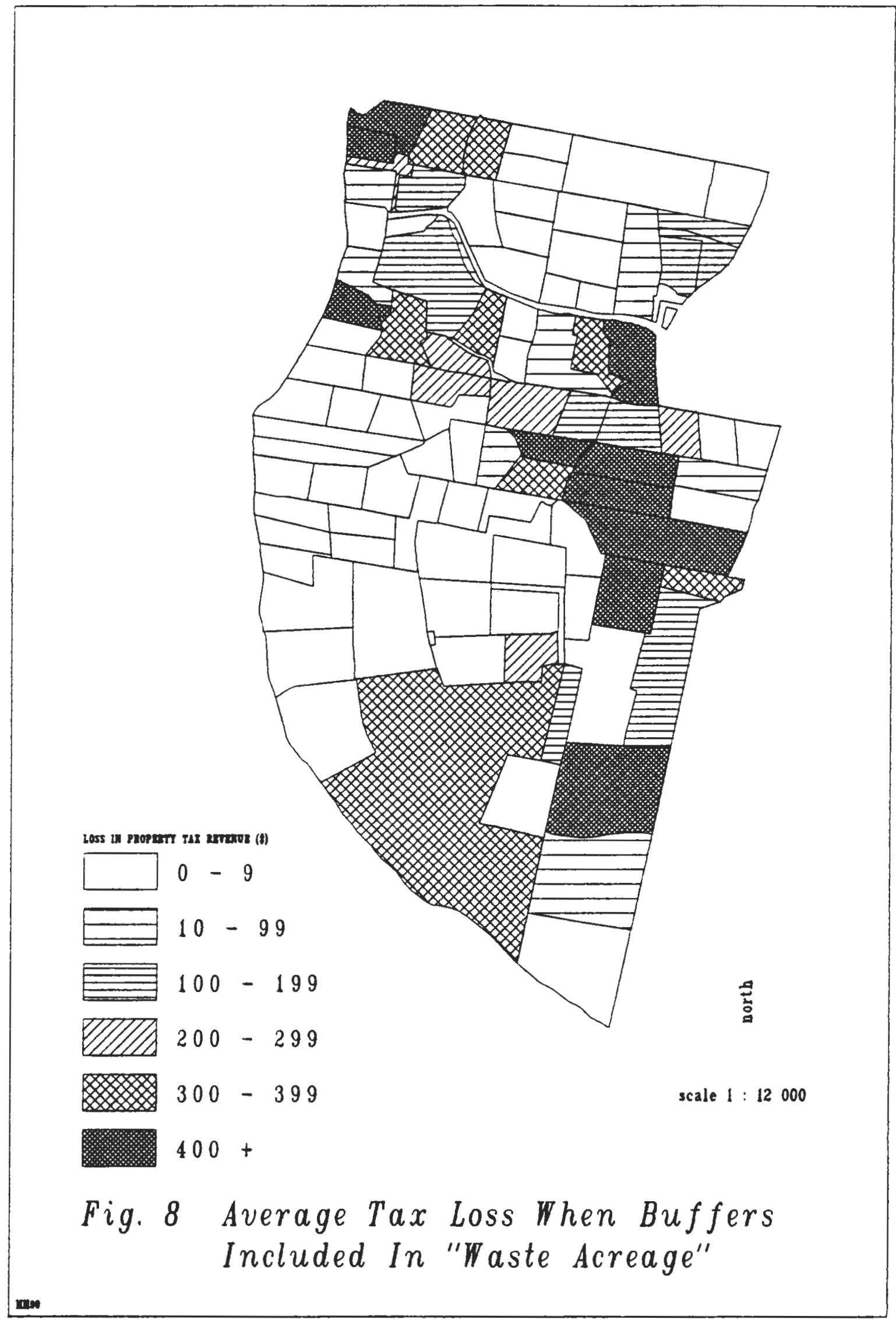


Also as a result, there would be an additional loss in property tax revenue when the buffer areas are included, approximately $\$ 3000$. This represents the difference between a loss of $5.77 \%$ when the buffers are excluded to 8.698 to when they are included. The implications of this difference could be most important at a commity-wide level.

\section{Increasing Buffer Widths Around Wetlands}

The fiscal impact analysis indicated that the amount of property tax revenue lost for Plat 14 was directly proportional to the width of the wetland buffer, and this rate remained constant in a linear form from 50 to 300 feet (see Table 4). If there had been a sharp increase in the tax loss when the buffer width was increased it could have been said that a buffer width less than this might be more satisfactory in terms of the fiscal effects. Nevertheless there was not a point where the buffer width could be maximized and the negative fiscal impacts minimized. This obviously may or may not hold true for other parts of the island or island as a whole.

Table 4 Estimated Fiscal Impacts from Increasing Buffer Widths Around Wetlands, Plat 14, Town of New Shoreham

\begin{tabular}{ccccc}
$\begin{array}{c}\text { Buffer Width } \\
\text { (feet) }\end{array}$ & $\begin{array}{c}\text { Waste Area } \\
\text { (acres) }\end{array}$ & $\begin{array}{c}\text { Tax Due } \\
(\$)\end{array}$ & $\begin{array}{c}\text { Tax Loss } \\
\text { (\$) }\end{array}$ & (8) \\
\hline existing 50 & 61.55 & $115,674.80$ & $10,903.941$ & - \\
100 & 131.81 & $100,605.53$ & $15,069.27^{2}$ & $(13.03)$ \\
200 & 168.45 & $91,567.51$ & $24,107.29^{2}$ & $(20.84)$ \\
300 & 204.46 & $81,787.05$ & $33,887.75^{2}$ & $(29.30)$
\end{tabular}

1 Tax loss based on 1987 database not up-dated $(\$ 126,578.74)$ and datbase updated with RIGIS wetlands including 50 ' buffer.

2 Tax loss based on updated database (RIGIS wetlands including 50' buffer). 
The tax loss is the difference between what property tax would be collected if the 1987 tax assessor's database incorporated the RIGIS fresh water wetlands data and the $50^{\prime}$ buffer widths around wetlands, to the total property tax revenue generated when the width of these buffers increased. The average estimate assumes that no spatial error exists around the wetlands data.

Figures 9, 10 and 11 represent the average tax loss per lot in the pilot study area of increasing the buffer widths to 100, 200 and 300 feet respectively. The total number of lots affected is clearly illustrated plus the buffered wetland. Table 5 summarizes the frequency of lots with tax losses from introducing the RIGIS wetlands and increasing the buffer widths.

Table 5 Frequency of Lots With Expected Property Tax Loss, Plat 14, Town of New Shoreham.

\begin{tabular}{crrrrr} 
Tax Loss & 0 & 50 & 100 & 200 & 300 feet \\
\hline \hline $0-9$ & 66 & 59 & 63 & 48 & 30 \\
$10-99$ & 9 & 8 & 5 & 7 & 7 \\
$100-199$ & 11 & 9 & 6 & 6 & 4 \\
$200-299$ & 3 & 6 & 3 & 7 & 5 \\
$300-399$ & 7 & 8 & 6 & 5 & 46 \\
$400+$ & 4 & 10 & 17 & 27 & 100 \\
\hline Total & 100 & 100 & 100 & 100 & - \\
\hline
\end{tabular}

The table shows that as buffer width increases the percentage of lots that could expect tax abatements through lower assessed land values rises sharply. When buffer width is increased to 300 feet there would be a property tax loss of $\$ 400$ or more on 468 of the lots, however only 10 of these lots would have been affected by the existing DEM regulation of 50 


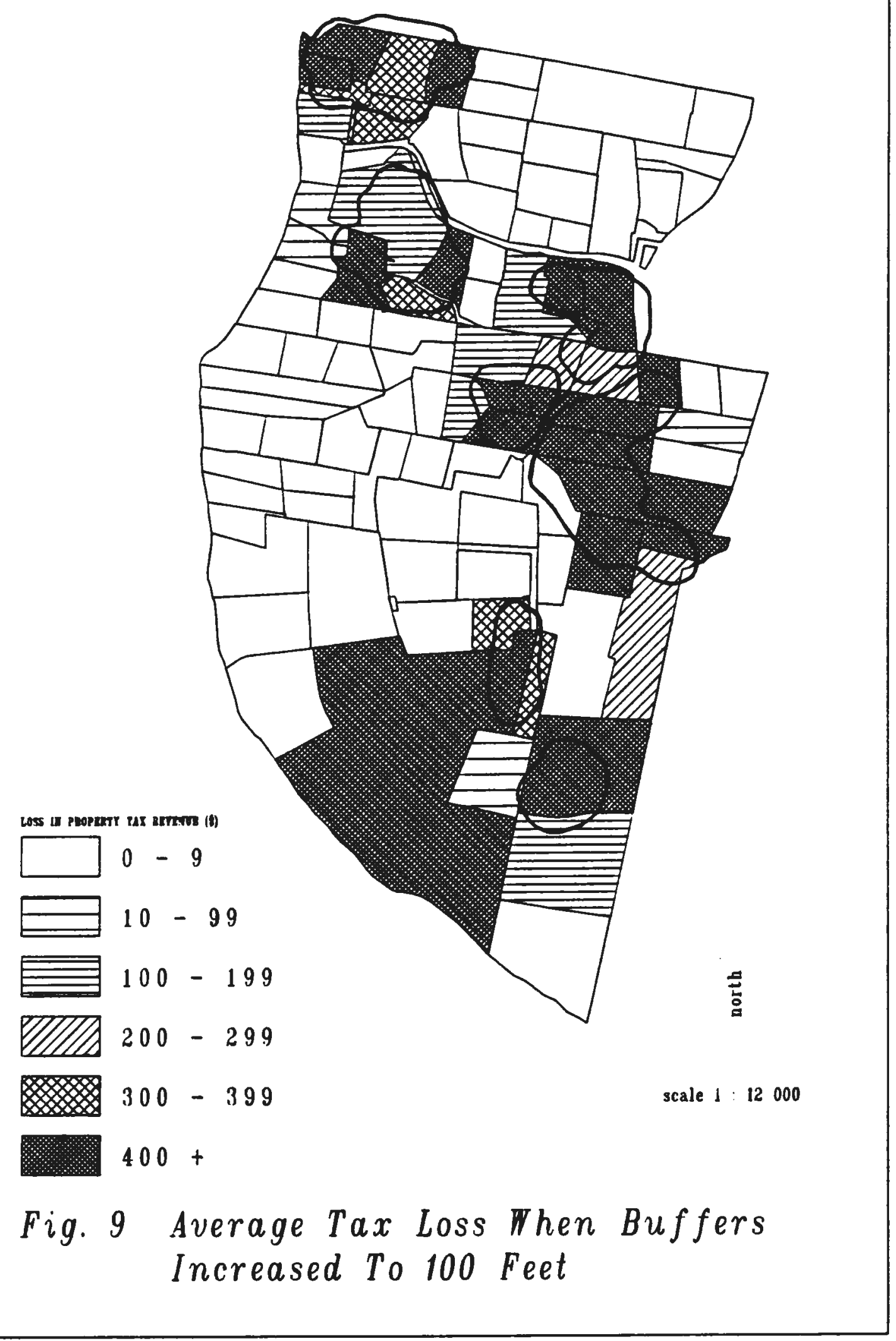




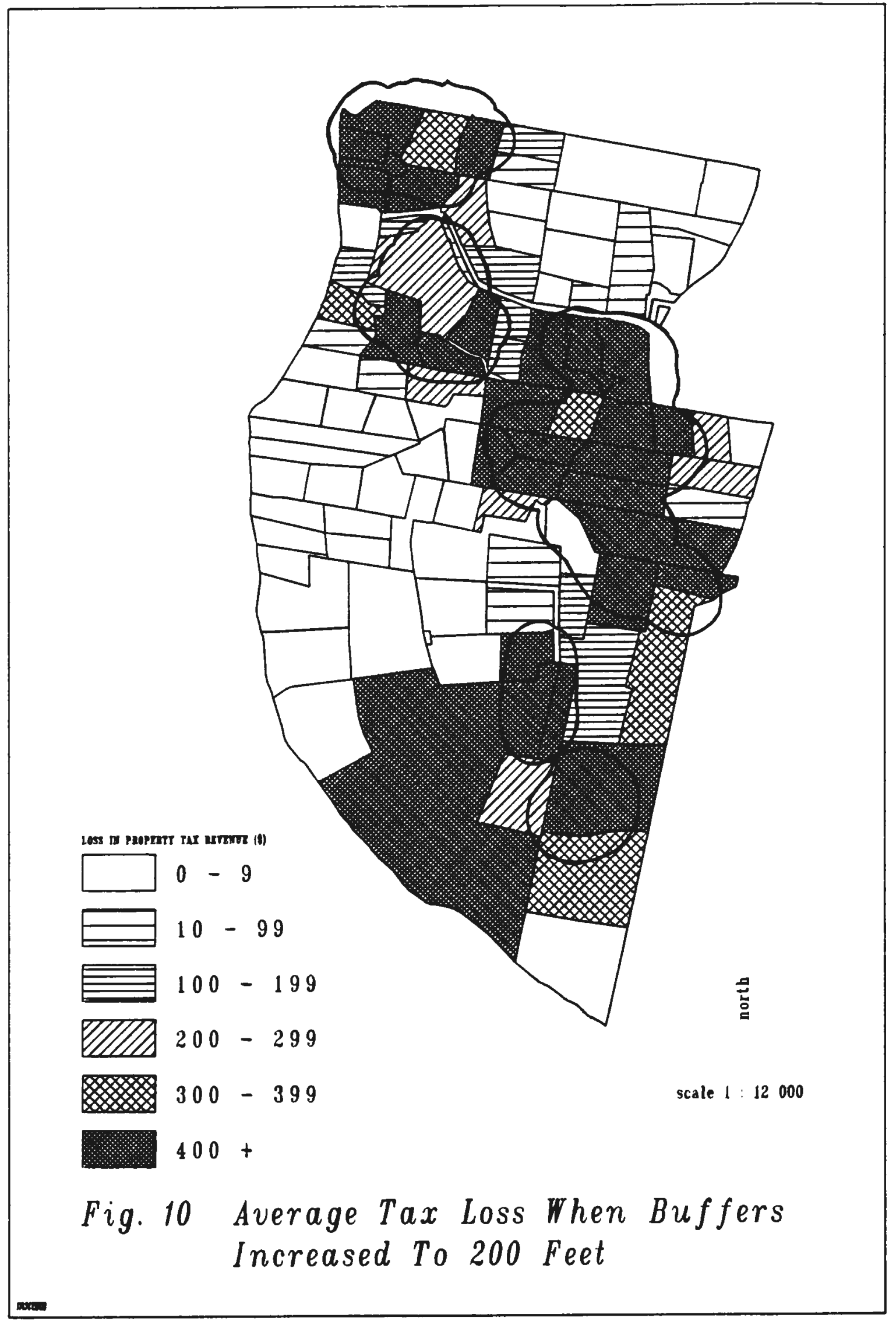




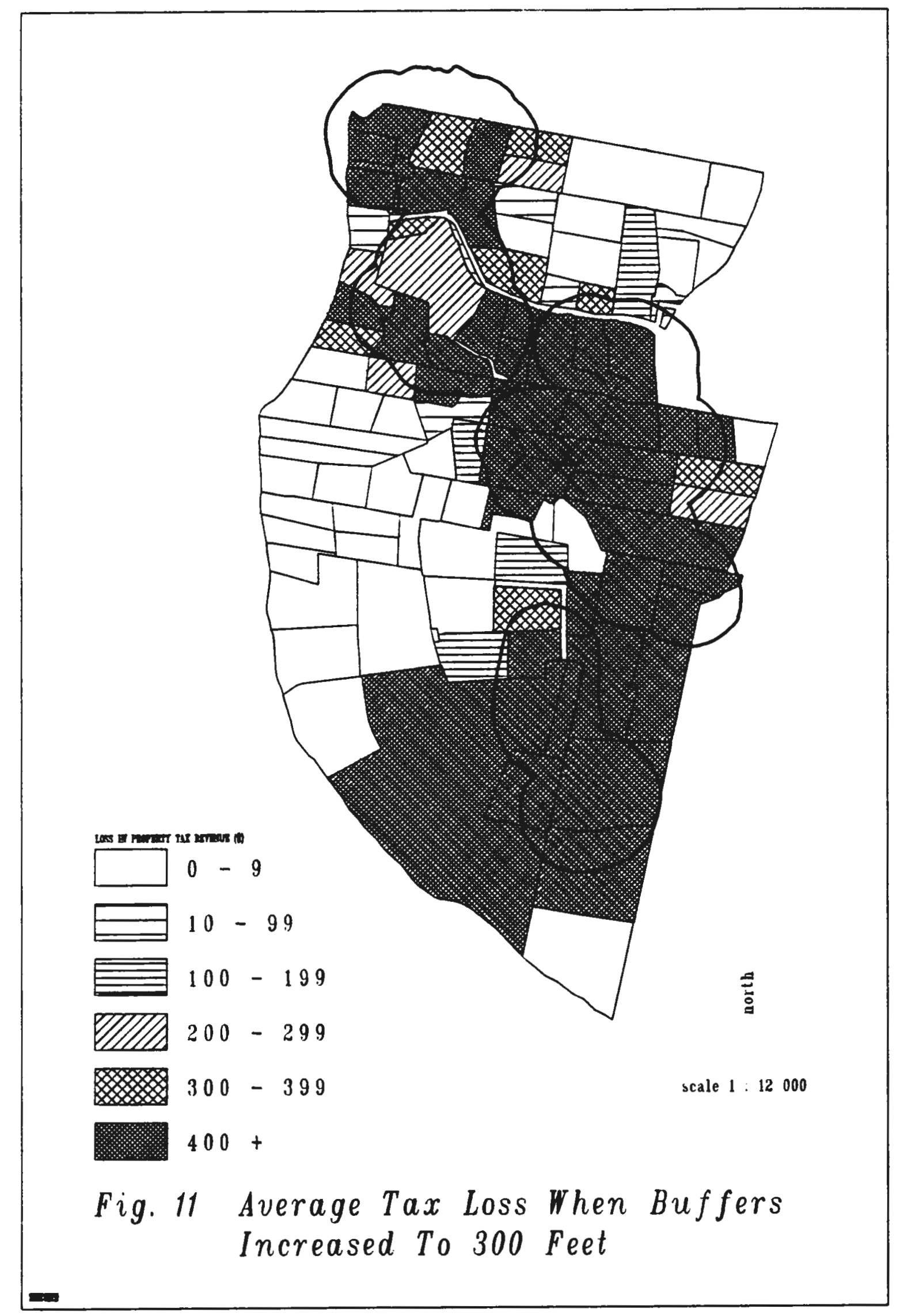


foot buffers. This contributes directly to the overall tax loss.

\section{Other Findings}

In developing and applying the FIA macro several limitations with the 1987 tax assessor's database were identified, which tend to make it difficult for use in its current form with the GIS. These limitations are not all insurmountable but reflect the original purpose of the database - to record details about the lots of record (ownership, area, land value, building value). As stated earlier, the 1987 database was the only one available at the time for use in this research. It is quite possible that some of the following matters may have been avoided (or minimized) through the use of a more up-to-date database which will be available shortly. The problems encountered in the use of the 1987 database are detailed below, along with the strategies used to alleviate them in this study.

\section{Duplication of Records}

To temporarily REIATE the lot coverage with the tax assessor's database there must be only a one-to-one correspondence for each lot of record. In other words, each record in either file can be matched to one, and only one, record in the other file. This is not the case with the 1987 database. When a lot of record has more than one owner and tax notices must be sent to more than one mailing address, there are separate records for each owner. For example, Plat 14, Lot 32 is recorded twice and Plat 14, Lot 20 three times. To correct this the duplicate records had to be deleted so only one record for each lot of record is remaining. Area Of Lots

The total area (BIACRES) of several lots did not agree with the area delineated on the tax assessor's plat. This would be expected if a lot 
had been surveyed and the new area used to up-date the database, however this does not appear to be the case. Whenever the area's differed, the area shown on the plat approximated that recorded in the digitized lot coverage's polygon attribute file. (This is not surprising since the plats were used for digitizing the lot coverage). For example, the total area of Plat 14, Lot 20, SubLot 6 is recorded as 2.0521 acres in the database, while the plat map and digitized lot .PAT file computes it as 3.66 and 3.77 acres, respectively. Similarly, the area of Plat 14, Lot 52 is listed as 3.50 acres, but 1.20 acres on the plat map and 1.125 acres in BELL.PAT - quite a considerable difference. (The small discrepancy between the plat figure and the lot's. PAT file is due to the automation process).

Inaccuracies were also noted in the figures for Lot Size, Excess Acreage and Waste Acreage and can be most likely attributed to inadequate proofing when the data was originally entered into the database. These discrepancies do not affect the results of the fiscal impact analyses since "Lot Size" is not used in any computations and new figures are computed for both "Excess" and "Waste".

The integration of area calculations from different sources for the same lot or parcel of land proved to be also a problem. Generally when at least $90 \%$ of a lot was subject to "Waste Acreage" (through the presence of wetlands from the RIGIS coverage), the area of the polygon (after the BUFFER and UNION spatial operations had been performed) was greater than the total area of the lot indicated in the tax assessor's database as BIACRES. This meant that the new "Waste Acreage" areas would be larger than the lot itself (BIACRES), resulting in a negative area for 
"Excess Acreage" being calculated. This obviously was not a satisfactory computation and would result in an inaccurate determination of the fiscal impacts.

To mitigate this the areas of the digitized lots from BELLl4.PAT were copied to TAX-DATAl4 and converted from square meters into acres. Despite the transformation process undertaken in the automation of the plats there is little difference between the total area of lots for Plat 14 shown in the tax assessor's database, tax assessor's plat map and the digital lot coverage (see Table 6 below).

Table 6 Comparison of Total Lot Area from Different Sources, Plat 14, Town of New Shoreham

\begin{tabular}{lc} 
Source & Acres \\
\hline \hline Digitized Lots & 342.47 \\
1987 Database & 337.90 \\
\hline Difference & 4.57 \\
\hline
\end{tabular}

1 Duplicate records were deleted and the area of lots adjusted to accord with the plat map.

This good correlation between the total lot areas for Plat 14 from these two data sources may not occur in other parts of the island, especially in the north where considerable shifts between the individually transformed plats and the the island-wide transformation occurred. A comparison between the total lot area from the tax assessor's database and digitized lots should be made, in conjunction with the digitizing of a more accurately defined coastline for the island, before introducing areas from BELL.PAT into the database on a community-wide basis. 


\section{Summary}

It is, of course not possible to generalize the results derived from the pilot study area analysis and predict that impacts of similar magnitude would occur in other parts of the municipality or even over the whole island. The level of accuracy and completeness of "Waste Acreage" in other parts of the Island have not been reviewed in any depth, although it was noted that the adjoining Plat 13 displayed a similar shortage of WA figures in comparison to the tax assessor's plat (comparison with RIGIS data was not made). The magnitude of tax loss on each lot, within each Plat and parts of the Town will differ due to the variable nature of land values, lot size and fresh water wetlands. These factors will also mean that the impact of increasing buffer widths around wetlands and the difference between maximum and minimum impact will fluctuate according to the characteristics of the area and lots. The implications of this on a local community's fiscal flow could be significant. 


\section{CONCIUSIONS AND POLICY IMPLICATIONS}

With communities in Rhode Island and throughout the United States looking for ways to balance economic growth and environmental protection, plus analyze the trade-off between tax loss and greater environmental protection, this proposed macro should be of assistance. The direct impacts on property tax revenues of a range of possible scenarios, such as increasing the buffer widths around wetlands, can be readily developed and the costs of proposed policy or regulations estimated.

By developing a number of different scenarios the implications of various buffer widths can be explored and quickly too. Through making the evaluation more explicit, systematic, comprehensive and quantitative the macro can assist in determining if a "win-win" situation occurs where the negative fiscal impact can be minimized and the buffer width increased.

If the width of buffers around wetlands in the future are to be determined on purely scientific grounds the implications of this on local property tax revenues could be significant. If a balance were to be sought between environmental protection and tax loss, with both the environmentalists and politicians compromising, a different buffer width could result.

The macro intends to assist a community, such as the Town of New Shoreham in obtaining additional technical information associated with changes in data collection techniques and environmental policies. The results could be easily comprehended by planners, politicians, 
environmentalists and citizen groups. The trade-offs however should still be weighed in light of community goals and social costs. It must be remembered though that even with the best impact measures, most up-todate and accurate information and advanced technology available, decisions are still likely to be made on political or emotional grounds. The use of this macro can help to lay some community fears at rest and at the same time decision-makers can be provided with improved information within an organized framework.

The storage of parcel-based information by a geographic information system means that now fiscal and spatial impact analyses can be readily performed, not only at a community-wide level, but also on a lot-by-lot basis. Fiscal and economic impact studies on changes in environmental policy, in particular one for the New Jersey Pinelands in 1980 (where wetland buffers were increased to 300 feet), was restricted in it's research methods by an inability to assess impacts at the parcel level:

The absence of more comprehensive analysis reflects in part the difficulty in obtaining and managing data for the appropriate geographical area and over a sufficiently long time period as well as methodological problems....

(Christian, 1980)

In this New Jersey study most of the analysis was at the municipal level, since data was not readily available at a large scale, the sheer size of the study area (four Townships) and difficulties in managing the vast amount of data and maps needed for such an analysis. Graphic and spatial representations were minimal. A GIS could have contributed in deleting such difficulties. 
The GIS is a new instrument in a planner's toolbox, enabling complex issues to be addressed in entirely new ways. It is a versatile, interdisciplinary tool for the automated analysis of spatial and tabular data. The integration of GIS with municipal databases is an efficient and effective method for fiscal impact analysis of proposed environmental policies. Time constraints prevented developing the macro to produce tabular reports and maps directly from it, both on-screen and as printout. The addition of these elements would improve the macro's reporting abilities for a community-wide analysis. In the meantime, attention is needed to improve and develop municipal geographic information systems to support such modelling development. 
Anderson, Glen D., \& S.F. Edwards. 1986. Protecting Rhode Island's Coastal Salt Ponds: An Economic Assessment of Downzoning. In Coastal Zone Management Journal. 14, 1/2.

ACSM. 1989. Multi-Purpose Geographic Database Guidelines for Local Governments. ACSM Bulletin. August 1989: 42-50.

August, P.V., W.R. Wright \& R.L. Bendick. Incorporating GIS Methods into the Natural Resource Manager's Toolbox: Lessons from the Rhode Island GIS Project.

Batie, S.S., \& L.A. Shabman. 1982. Estimating the Economic Value of Wetlands: Principles, Methods, and Limitations. In Coastal Zone Management Journal. 4: 255-278.

Brail, R.K. 1987. Microcomputers in Urban Planning Management. Rutgers, New Jersey.

Brady, Peg \& Robert Buschbaum. 1989. Buffer Zones: The Environment's Last Defense. A report submitted by Massachusetts Audobon: North Shore to City of Gloucester, Massachusetts.

Christian, Nichols et al. Economic Analysis of Pinelands Comprehensive Management Plan. Nov 20, 1980.

Collins, B.R. and Emily W.B. Russell, ed. 1988, Protecting the New Jersey Pinelands, A Direction in Land-Use Management. Rutgers University Press.

Cowardin, L.M., V. Carter, F.C. Golet \& E.T. LaRoe. 1979. Classification of Wetlands and Deepwater Habitats of the United States. U.S. Department of the Interior, Fish and wildlife Service.

Diamond, R.S., and D.J. Nilson. 1988. Buffer Delineation Method For Coastal Wetlands In New Jersey. Symp. Coast. Water Res., Amer. Water Res. Assoc. May 1988.

Environmental Systems Research Institute, Inc. 1987. AML User Guide: Redlands, California. 
IEP, Inc. 1990. Hunt-Potowomut Watershed - Development of a Vegetated Buffer Strip (VBS) Guidance Manual. Prepared for The Land Management Project.

Groffman, P.M., A.J. Gold, T.P. Husband, R.C. Simmons \& W.R. Eddleman. 1990. An Investigation Into Multiple Uses of Vegetated Buffer Strips. Final Report - Narragansett Bay Project. Dept. Natural Resources Science, University of Rhode Island, Kingston, R.I.

Guptill, Stephen C. ed. 1988. A Process For Evaluating Geographic Information Systems. Technology Exchange Working Group - Technical Report 1. Federal Intragency Coordinating Comittee on Digital Cartography 1988. U.S. Geological Survey Open-File Report 88-105.

Hooker J.H. \& Mary F. Hutchinson. 1989. Scale Integration: The Implications. Unpublished Research Paper for NRS410 GIS Methods in Environmental Management, Natural Resource Science, University of Rhode Island, Kingston, RI.

Levine, J. \& J.D. Landis. 1989. Geographic Information Systems for Local Planning. APA Journal. Spring 1989: 209-220.

McLaughlin, D.K., \& T.R. Alter. 1989. Fiscal Capacity Analysis. Participant's Notebook. NorthEast Regional Center for Rural Development.

Schaenman, Philip S. \& Thomas Muller. 1974. Measuring Impacts of Land Development - An Initial Approach. The Urban Land Institute. Washington, D.C.

Smith, C.G., L. Thompson, \& P.V. August. 1989. Error In Spatial Data: A Practical View. Proceedings of 9th Annual ESRI User Conference, Palm Springs, California.

Smith, Harry A. 1989. An Evaluation and Case Study of the Potential for Development of a Detailed Database By a Joint Participant for use with Geographic Information Systems. A Research Project in partial fulfillment of the requirements for the degree and master of Community Planning, University of Rhode Island.

Swartzman, Daniel, Liroff, R.A. \& Kevin G.Croke, editors. 1982. CostBenefit Analysis and Environmental Regulations. The Conservation Foundation. Washington, D.C. 
Thompson, L. 1989. Block Island Data Availability and Documentation. Unpublished notes.

Tiner, R.W. 1989. Wetlands of Rhode Island. U.S. Fish \& Wildlife Service, National Wetlands Inventory, Newton Corner, MA.

Town of New Shoreham. Subdivision Regulations New Shoreham, Rhode Island. Adopted December 20, 1982.

Town of New Shoreham. 1989. Zoning Ordinance Town of New Shoreham. 1989 amend. 